\title{
浅谈路桥工程造价中主要工程量的计算总则
}

\author{
秦兆平 夏津 \\ 武汉市工程咨询部 \\ DOI:10.32629/btr.v2i12.2744
}

[摘 要] 造价工程量在计算过程中,必须要科学合理的进行工程量计算,做好工程概预算工作。因此需要将施工图纸进行全面的掌握,在概预算 编制的过程中,将工程概预算工程量的计算要点进行分析,从而提高路桥工程概预算水平。

[关键词] 道路工程; 概预算编制; 工程量

\section{1 土石方工程概预算编制主要的工程量计算分析}

1. 1 路基土石方的开挖。土石方工程一般包括土方工程、石方工程、 回填及其他。具体说来, 土壤按一、二类土, 三类土, 四类土进行分类; 岩 石按极软岩、软岩、较软岩、较硬岩、坚硬岩分类。同时, 土石方的压实、 运输, 按石方和土方两者的体积之和计算。

1. 2 施工机具的经济运距问题。汽车的运距如果在 $500 \mathrm{~m}$ 以内, 则不能够 将其长距离运输的优势充分发挥出来, 对于近距离的土石方运输, 一般考 虑为装载机转运, $1 \mathrm{~km}$ 及更远距离可考虑为自卸汽车运输。对中型推土机来 说, 推移土石方的经济距离在 $50 \mathrm{~m} \sim 100 \mathrm{~m}$ 范围内, 超过经济运距, 则失去了 其经济性。为了合理经济的确定路基土石方的运输单价, 需要结合不同类 型机械各自的特点, 对经济运距有准确的把握, 根据实际需要选择合适的 机械, 为土石方运输成本计算提供合理地参考。

1. 3土石方的开挖、运输均按开挖前的天然密实体积计算。土方回填, 按回填后的竣工体积计算。所以, 定额中明确指出的换算系数在当借土填 筑路堤、移挖作填计算中发挥着至关重要的作用。

1.4 土方回填工程中, 按照实际情况的差异, 决定酒水的量的多少。如 果施工现场没有酒水, 可以不考虑此项费用。

1. 5 土石方工程中的弃运土方。土石方工程中, 挖填方总量保持一致, 是计算土石方工程量的主要指标, 即我们通常说的挖填方平衡。总的挖方 量等于总的填方量和总的弃运土方工程量之和。综合考虑挖填方平衡, 使 多余土方均衡运转在路基土石方工程中十分重要。同时, 采土场和弃土场 地点的选择, 也是影响土石方单价的主要因素。

\section{2 道路工程概预算编制主要的工程量计算分析}

2. 1 土石方工程: 现状地面杂填土及建筑垃圾的分布情况, 沿线路基土 方的类别, 直接影响着挖路槽的土石方的单价, 而路基横断面的尺寸直接 影响着挖路槽的土石方体积的大小, 做好项目勘察工作, 熟悉项目施工环 境对土石方工程量的计算非常重要。

2. 2 路基工程: 依据规范要求, 各类级配砾石路面、稳定土基层级配碎 石的压实厚度在应小于 $15 \mathrm{~cm}$, 垫层和其他种类的基层压实厚度应不超过 $20 \mathrm{~cm}$, 而填隙碎石一层的压实厚度控制在 $12 \mathrm{~cm}$ 范围内, 施工过程中, 需严格 按照规范标准进行施工, 造价人员也需要按照相应规范计算基层的分层厚 度。如果根据现场实际情况, 回填路基需要进行分层推铺, 养护时, 套用定 额需考虑相应的调整系数。

2. 3沥青面层：粘层、透层定额是概预算定额的重要组成部分。根据
规范要求, 一般在沥青混合料的铺筑工程之前, 对完工的基层上酒布透层 油。水泥混凝土路面上、旧沥青路面, 各沥青面层直接喷酒粘层油, 这也是 计算工程量不容忽视的内容。

2. 4 人行道步砖：需按照设计图纸, 区分不同材质和规格, 进行工程量 的统计, 一般计量单位为 $\mathrm{m}^{2}$ 。

2.5道路附属工程：站卧石、花池等道路附属工程,需要按照设计图 纸, 计算相应的基层和长度, 花池设在人行道时, 需扣除相应的步砖面积。

\section{3 桥梁工程概预算编制主要的工程量计算分析}

3.1 下部结构。(1)地基工程。基坑开挖应经过实际考察后, 按土方、淤 泥、石方等分别统计, 土石方换填、搅拌桩、砌石、沉井、打桩等是基础 工程的常见处理方式。工程量计算时应考虑到现状地面高程和设计高程的 高差, 以免造成漏算少算。(2)桩基工程。桩基工程因钻进较深, 地质情况较 为复杂, 通常一根桩基会出现多种不同的地质类型, 在工程量计算过程中, 需区分桩径大小, 对应地质钻探资料, 合并计算相同类型的钻进地质。钻进 工程量以长度计算, 同时应充分考虑现状地面高程、桩顶设计高程、桩底 设计高程之间的关系, 准确计算桩基长度。对围堰筑岛填心的水中施工来 说, 桩底设计高程、围堰的顶面高程则是计算时的关注要点。(3)系梁、墩 台。其常见结构体系包括承台、系梁、桥台、墩柱和搭板。搭板上层路面 一般在路面工程计算中予以考虑。雉坡、台背的土方一般在土石方工程中 考虑, 无需重复。墩台的计价则必须将各方面因素都考虑进来, 包括翼墙、 耳背墙, 墩台身及其拱、盖梁、墩台帽等, 以 $\mathrm{m}^{3}$ 计算。

3. 2 上部结构。其结构形式一般包括钢析架和钢索吊桥、砌石、预制 安装混凝土构件、现浇混凝土、钢制梁段拼接等。由梁段、桥面铺装、人 行道、行车道组成。该上部梁段部位是工程设计的重点, 工程量计算较为 复杂, 需仔细对照各断面图纸区分各梁段分别计算, 并充分考虑支架安拆 和吊装转运等因素, 桥面铺装等附属工程则按照面积进行计算, 有效防止 遗漏或者重复算量。

[参考文献]

[1]谢旺祥,熊艳.提高公路工程概预算准确性途径[J].黑龙江交通科 技,2017,40(12):205-206.

[2]徐继红.提高公路工程概预算编制的准确性[J].淮北职业技术学院 学报,2010,9(03):9-10.

[3]浦恩辉,卢伟.提高公路工程概预算准确性途径的探讨 [J].四川建 材,2016,42(04):263-264. 